\title{
En mann i 60-årene med brystsmerter og funksjonsdyspné
}

\author{
Mannen i 60-årene ble innlagt i sykehus etter dyspné og akutt innset- \\ tende ubehag i høyre arm. Man mistenkte hjerteinfarkt. Men historien \\ illustrerer at bak noen av de vanligste symptomene man møter ved \\ indremedisinske avdelinger, kan det skjule seg sjeldne og alvorlige \\ tilstander hvor rask og korrekt diagnose har store behandlingsmessige \\ konsekvenser.
}

En mann i 60-årene ble innlagt i lokalsykehus på grunn av dyspné og akutt innsettende ubehag i høyre arm. Ved innkomst kunne pasienten fortelle at han den siste måneden hadde hatt gradvis økende funksjonsdyspné og pressende smerter retrosternalt både ved aktivitet og i hvile. De siste to ukene hadde han hatt nattlig dyspné, og en uke før innleggelsen hadde han et flere timer langt anfall med kraftige brystsmerter. Han hadde da oppsøkt sin primærlege, som tolket brystsmertene til å være relatert til luftveiene og ikke-kardiale. Han fikk ibuprofen, med god effekt på smertene.

Ved innleggelsen var pasienten i god allmenntilstand, med blodtrykk $150 / 100 \mathrm{~mm} \mathrm{Hg}$, puls $107 \mathrm{slag} / \mathrm{min}$, temperatur $37,1^{\circ} \mathrm{C}$, respirasjonsfrekvens på 16 og oksygenmetning $93 \%$ på romluft. Huden var blek. Han hadde systolisk bilyd grad 2, og over lungene var det ekspiratoriske pipelyder samt basale knatrelyder bilateralt. EKG (fig 1) viste sinustakykardi, høyre akse, inkomplett høyre grenblokk, mindre Q-bølger i V1-V6 og ST-elevasjon på 1-2 mm i V3-V5.

Initiale blodprøver (tab 1) viste troponin I på $38059 \mathrm{ng} / \mathrm{l}$, leukocytter $21,0 \cdot 10^{9} \mathrm{celler} / \mathrm{l}$, CRP $20 \mathrm{mg} / \mathrm{l}$, ASAT $102 \mathrm{U} / \mathrm{l}$, ALAT $108 \mathrm{U} / \mathrm{l}$, ALP $254 \mathrm{U} / \mathrm{l}$, bilirubin $29 \mu \mathrm{mol} / \mathrm{l}, \mathrm{GT} 251 \mathrm{U} / \mathrm{l}$ og normalverdier for kreatinin, elektrolytter, glukose og trombocytter. Røntgen thorax viste forstørret hjerte og stuvning. Ekkokardiografi viste redusert veggfortykkelse ltegn på redusert kontraktilitet) svarende til forsyningsområdet til fremre nedadstigende gren av venstre koronararterie.

Pasienten fikk $i$ henhold til retningslinjer for akutt koronarsyndrom (1) dobbelt blodplatehemming med acetylsalisylsyre og ticagrelor, antikoagulasjonsbehandling med enoksaparin, høydose atorvastatin og metoprolol. Han ble overflyttet til universitetssykehus for koronar angiografi.

Pasienten hadde ingen brystsmerter ved innkomsten, men EKG-undersøkelse, ekkokardiografiske funn og anamnese ga mistanke om at pasienten hadde gjennomgått et transmuralt hjerteinfarkt. Det var derfor klar indikasjon for invasiv hjerteutredning $(1,2)$.

Pasienten hadde lav risikoprofil for koronarsykdom - han var til vanlig fysisk aktiv, var ikke-røyker, hadde ikke kjent diabetes, hypertensjon eller hyperkolesterolemi, og det var ingen familiær belastning for koronarsykdom. Koronar angiografi utført dagen etter overflyttingen viste mindre veggforandringer, men ingen signifikante stenoser ( $\geq 50 \%$ reduksjon $i$ karlumendiameter) $i$ koronarkarene (fig 2).

To dager etter overflyttingen viste ny ekkokardiografisk undersøkelse lett dilatasjon og betydelig redusert funksjon av både høyre og venstre ventrikkel. Venstre ventrikkels ejeksjonsfraksjon ble estimert til omtrent $25 \%$ (normalt 55-70\%). Det var regionale kontraksjonsforstyrrelser fordelt over store deler av venstre ventrikkels myokard, og disse forandringene var ikke lokalisert apikalt, midtventrikulært eller basalt, slik man ser ved takotsubokardiomyopati.

Det ble ikke sett organiserte tromber, men det var betydelig spontankontrast $i$ apikale halvdel av venstre ventrikkel. Det forelå moderat pulmonal hypertensjon (systolisk pulmonalarterietryk $50 \mathrm{~mm} \mathrm{Hg}$, normalt $<30 \mathrm{~mm} \mathrm{Hg}$ ), og det var store regionale forskjeller $i$ veggfortykkelse, uten at dette passet med koronare forsyningsområder (fig 3, video 1).

Pasienten hadde utviklet en alvorlig hjertesvikt med symptomer i hvile - New York Heart Association (NYHA) klasse IV. Det var beskjedne funn ved koronar angiografi, og de kunne ikke forklare den betydelige reduksjonen i venstre ventrikkels funksjon. De regionale forskjellene i kontraktilitet passet heller ikke med takotsubokardiomyopati. EKG med ST-T-forandringer og høyt troponin I-nivå gjorde at man nå mistenkte myokarditt. Ticagrelor ble seponert, mens pasienten fortsatt fikk acetylsalisylsyre og

\section{Tobias S. Slørdahl}

tobias.s.slordahl@ntnu.no Klinikk for hjertemedisin St. Olavs hospital og

Institutt for kreftforskning og molekylærmedisin Norges teknisk-naturvitenskapelige universitet

\section{Brage H. Amundsen}

Klinikk for hjertemedisin

St. Olavs hospital

og

Institutt for sirkulasjon og bildediagnostikk

Norges teknisk-naturvitenskapelige universitet

Øystein Størkersen

Avdeling for patologi og medisinsk genetikk St. Olavs hospital

\section{Knut Haakon Stensæth}

Klinikk for bildediagnostikk

St. Olavs hospital

og

Institutt for sirkulasjon og bildediagnostikk Norges teknisk-naturvitenskapelige universitet

\section{Morten Kristian Slette}

Klinikk for hjertemedisin

St. Olavs hospital

\section{Rune Wiseth}

Bjørnar Grenne

Klinikk for hjertemedisin

St. Olavs hospital

og

Institutt for sirkulasjon og bildediagnostikk

Norges teknisk-naturvitenskapelige universitet

e-fig 4 og e-fig 5 finnes i Tidsskriftets elektroniske utgaver

Video på www.tidsskriftet.no 


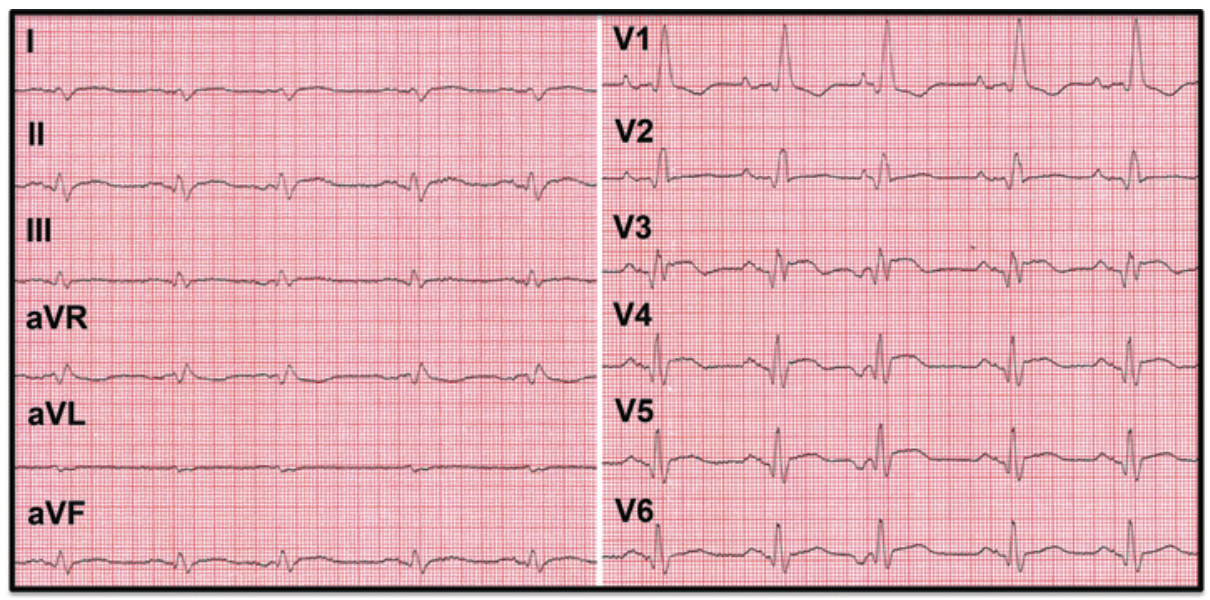

Figur 1 EKG ved innleggelse viste sinustakykardi, supraventrikulære ekstrasystoler, inkomplett høyre grenblokk, høyre akse, dårlig R-progresjon i prekordialavledningene, mindre Q-bølger i V1-V6 og ST-elevasjon på 1-2 mm i V3-V5. Papirfart $50 \mathrm{~mm} / \mathrm{sek}$

statin på grunn av påviste veggforandringer i koronararteriene.

Myokarditt defineres som en inflammasjon i myokard og diagnostiseres etter etablerte histologiske, immunologiske og immunhistokjemiske kriterier (3). På grunn av dens vevskarakterisende evne og høye romoppløsning har kardial magnetisk resonans (MR) gitt ny innsikt i myokardittrelaterte skader. Ved hjelp av MR-undersøkelse kan man måle endringer over tid, og undersøkelsen er viktig for å kunne skille mellom aktuelle diagnoser (4).

Forløpet ved myokarditt kan variere fra subklinisk tilstand til alvorlig hjertesvikt og plutselig død. De vanligste symptomene er brystsmerter, slapphet, nedsatt fysisk kapasitet, hjertebank og synkope. Myokarditt kan forårsakes av både infeksiøse og ikkeinfeksiøse tilstander, og virusinfeksjoner er vanligst. Ikke-infeksiøse årsaker kan være kardiotoksiner, hypersensitivitetsreaksjoner, systemiske sykdommer og stråling (5).

Ved grundig gjennomgang av anamnesen kom det frem at pasienten de siste ti årene hadde vært mye plaget med nesetetthet, tetthet i luftveiene og multiple sinusitter. Tre år før innleggelsen fikk han fjernet polypper i begge nesekaviteter. Etter dette hadde han hatt nedsatt luktesans. Han hadde også fått diagnosen astma. Et halvt år før innleggelse merket han dyspné når han gikk i trapper, og han måtte etter hvert sitte oppreist i sengen om natten for å få puste. Fastlegen hadde forskrevet et kombinasjonsinhalasjonspreparat med adrenergikum og kortikosteroid samt en kur med prednisolon. Pasienten merket etter dette en betydelig bedring.

Noen måneder før den aktuelle innleggelsen hadde han vært til ny vurdering hos ørenese-hals-lege, og da ble det oppdaget nye polypper. Én måned før innleggelsen fikk han en ny forverring av sin dyspné, og fastlegen forskrev igjen kombinasjonsinhalasjonspreparat med adrenergikum og kortikosteroid samt en ny kur med prednisolon og doksysyklin. Igjen opplevde han rask bedring, men forverring når han seponerte prednisolon. På slutten av doksysyklinkuren fikk han brystsmerter, som ble lindret av ibuprofen. Han hadde vært til vurdering hos kardiolog fire uker før innleggelsen. Det var da normal ekkokardiografi, bortsett fra en lett dilatert aorta ascendens.

Siden vi mistenkte myokarditt, ble det tatt supplerende blodprøver, inkludert serologiske og revmatologiske prøver med tanke på systemsykdommer (tab 1). Pasienten hadde ikke vært i tropiske strøk. Han hadde kun tatt medikamenter forskrevet av sin lege, inklusive doksysyklin, prednisolon, Symbicort og ibuprofen.

Pasienten bodde på gård, med sau, hest og esel, og jobbet som elektriker. Han ble årlig bitt av 1-2 flått, men hadde aldri observert erythema migrans. Han ble henvist til MR-undersøkelse av hjertet som ledd i den videre utredning. Differensialtelling av leukocytter viste at pasienten hadde $9040 \cdot 10^{6}$ eosinofile celler/l Inormalt 40-450 $\cdot 10^{6} \mathrm{cel}$ ler/l). Oppmerksomheten ble derfor dreid mot eosinofile tilstander, som kan forårsake myokarditt.

Eosinofili kan graderes som mild (500-1 500 $\cdot 10^{6}$ celler/), moderat (1 500$5000 \cdot 10^{6}$ celler/l) og alvorlig (> 5000 . $10^{6}$ celler/l). Vår pasient hadde alvorlig eosinofili. Perifer eosinofili kan deles inn etter etiologi: primær (hematologisk malignitet), sekundær eller idiopatisk.

Medikamentinduserte hypersensitivitetsreaksjoner og hypereosinofile syndromer kan gi myokarditt. Medikamentreaksjoner med eosinofili og systemiske symptomer forekommer sjelden, men kan utløses av for eksempel allopurinol og antiepileptiske medikamenter. Det kliniske bildet ved medikamentinduserte hypersensitivitetsreaksjoner inkluderer oftest feber, slapphet, lymfadenopati og et morbilliformt utslett, noe som ikke var eller hadde vært til stede hos vår pasient. Anamnesen bekreftet at dyspnésymptomene kom før pasienten fikk doksysyklin.

Pasientens eosinofili, sammenholdt med en mangeårig forhistorie med allergisk rhinitt, nasal obstruksjon, nasal polypose, recidiverende sinusitter samt astma diagnostisert i voksen alder ga mistanke om eosinofil granulomatose med polyangiitt (Churg-Strauss' syndrom). Dette ble støttet av anamnestisk god effekt av inhalasjonssteroider og prednisolon og akutt forverring etter kortvarig seponering av inhalasjonssteroidene og avsluttet prednisolonkur.

Høyresolusjons-CT viste forstørrede lymfeknuter i mediastinum samt uttalt interstitielt ødem med fortykkede interlobulærsepta. Perihilært og deklivt ble det sett mattglassfortetninger og uregelmessige konsolideringer. Basalt og lateralt på venstre side ble det sett opptil $1 \mathrm{~cm}$ store knuter subpleuralt. Det var moderate mengder pleuravæske bilateralt.

Bildet var mest forenlig med hjertesvikt med lungestuvning og eventuelt infeksjon. Konsolideringer $i$ underlappene kan være forenlig med eosinofile infiltrater, men er ikke spesifikke for dette. CT av bihulene viste betydelige slimhinnefortykkelser $i$ alle bihuler. MR cor viste dilatert venstre ventrikkel med et endediastolisk volum på $319 \mathrm{ml}$ (normalt 65-240 ml) og en ejeksjonsfraksjon på $20 \%$.

Det ble sett en mindre apikal trombe og omfattende subendokardialt forsinket kontrastopptak etter 10-12 minutter som uttrykk for fibrose/nekrose, godt forenlig med iskemi forårsaket av vaskulitt i små kar le-fig 4, video 2). Dagen etter ble det tatt endomyokardial biopsi. I påvente av biopsisvaret ble det startet, på klinisk, biokjemisk og radiologisk mistanke, behandling for eosinofil granulomatose med polyangiitt.

Behandlingen av eosinofil granulomatose med polyangiitt er primært glukokortikoider. Ved alvorlig eller refraktær sykdom legger man til annen immunsuppressiv behandling (6). Da pasienten hadde alvorlig vaskulitt med hjerteaffeksjon, var det indikasjon for å starte med høye doser med glukokortikoider intravenøst. Anbefalt er $1000 \mathrm{mg}$ metylprednisolon $\times 1$ i tre dager.

På bakgrunn av pasientens alvorlige hjertesvikt valgte vi å redusere dosen til $500 \mathrm{mg} \times 1 \mathrm{i}$ tre dager, ettersom høydoserte kortikosteroider kan gi væskeretensjon og forverring av sviktsymptomer. Deretter gikk han over til peroral prednisolon $(60 \mathrm{mg} \times 1)$ 
i nedtrappende doser. Pasienten fikk cyklofosfamid på dag 4 etter oppstart med steroider. Ved infusjon av cyklofosfamid skal pasienten hydreres godt (anbefalt 31 væskeinntak per døgn). På grunn av hans alvorlige hjertesvikt valgte vi å redusere litt på væskeinntaket, og han fikk furosemid $20 \mathrm{mg} \times 3$ intravenøst. Pasienten fikk økende ødemer i eina etter kuren, men disse gikk gradvis tilbake. På grunn av trombe i venstre ventrikkel ble det startet med antikoagulasjonsbehandling i form av warfarin.

Pasienten pustet lettere allerede samme dag som han fikk sin første dose metylprednisolon, og etter tre doser beskrev han betydelig tilbakegang av alle symptomer. Hudfargen ble bedre, han kjente lukt for første gang på flere år og kunne ligge flatt hele natten gjennom uten dyspné. Hjertebiopsien viste kronisk aktiv betennelse med eosinofile granulocytter og infarktforandringer (e-fig 5). Funnet var forenlig med eosinofil myokarditt med infarktforandringer, slik det er beskrevet ved myokardaffeksjon ved eosinofil granulomatose med polyangiitt.

Pasienten ble observert $i$ avdelingen med telemetri i ytterligere en uke. Siste ekkokardiografikontroll før utreise viste en liten bedring i ejeksjonsfraksjon, til ca. 30\%. Han hadde under oppholdet flere korte løp med asymptomatisk ventrikkeltakykardi. På bakgrunn av dette fikk han implantert defibrillator limplantable cardioverter-defibrillator - ICD).

Pasienten hadde alvorlig hjertesvikt, og flere av symptomene gikk tilbake etter oppstart av behandling. Han hadde hatt flere episoder med ikke-vedvarende ( $<30 \mathrm{~s})$ asymptomatisk ventrikkeltakykardi, og det ble på bakgrunn av dette besluttet å implantere kardioverterdefibrillator.

ICD som primærprofylakse ved hjertesvikt anbefales ut fra følgende kriterier: ejeksjonsfraksjon $\leq 35 \%$ på tross av tre måneder med optimal medikamentell behandling, forventet levetid over ett år med god funksjonell status og iskemisk etiologi (7). Hos pasienter med ikke-iskemisk dilatert kardiomyopati, ejeksjonsfraksjon $<36 \%$ og premature ventrikulære komplekser eller ikke-vedvarende ventrikkeltakykardi fant man en signifikant reduksjon i risiko for plutselig arytmidød med ICD sammenliknet med optimal medikamentell behandling (8).

Retningslinjene anbefaler at man behandler hjertesvikt optimalt medikamentelt $i$ tre måneder før eventuell implantasjon av ICD, men siden det, etter det vi vet, ikke finnes noen studier på risikoen for arytmidød hos pasienter med alvorlig svikt som følge av eosinofil infiltrasjon i myokard, valgte vi å tilby pasienten en primærprofylaktisk ICD.

Tabell 1 Oversikt over de mest relevante blodprøvene ved innkomst ved henholdsvis lokalsykehus og universitetssykehus samt ved utreise fra sykehuset. Andelen eosinofile granulocytter steg initialt under oppholdet ved universitetssykehuset og er derfor angitt også med høyeste verdi under oppholdet. Referanseverdier angitt i kolonnen lengst til høyre. Verdier utenfor referanseområdet er markert i halvfet

\begin{tabular}{|c|c|c|c|c|}
\hline Analyse & $\begin{array}{l}\text { Ved lokal- } \\
\text { sykehus }\end{array}$ & $\begin{array}{c}\text { Ved universitets- } \\
\text { sykehus }\end{array}$ & Ved utreise & $\begin{array}{c}\text { Referanse- } \\
\text { verdier }\end{array}$ \\
\hline $\mathrm{Na}(\mathrm{mmol} / \mathrm{l})$ & 140 & 132 & 141 & $137-145$ \\
\hline $\mathrm{K}(\mathrm{mmol} / \mathrm{l})$ & 4,3 & 4,1 & 3,7 & $3,5-4,4$ \\
\hline Kreatinin ( $\mu \mathrm{mol} / \mathrm{l})$ & 64 & 76 & 62 & $60-105$ \\
\hline Hemoglobin (g/100 ml) & & 13,6 & 14,5 & $13,4-17,0$ \\
\hline Leukocytter (10\%/l) & 21,0 & 15,0 & 6,7 & $3,7-10$ \\
\hline Nøytrofile (\%) & & 65 & 50 & $47-75$ \\
\hline Lymfocytter (\%) & & 18 & 29 & $21-43$ \\
\hline Monocytter (\%) & & 6 & 10 & $4-14$ \\
\hline Basofile (\%) & & 1 & 0 & $0-2$ \\
\hline Eosinofile (\%) & & $11-9$ & 1 & $1-4$ \\
\hline Eosinofile (106/l) & & $\begin{array}{l}1650 \cdot 10^{6} \\
7490 \cdot 10^{6}\end{array}$ & 67 & $40-450$ \\
\hline Troponin-I (ng/l) & 38059 & & & $\leq 28$ \\
\hline Troponin-T (ng/l) & & 3043 & 392 & $0-14$ \\
\hline NT-proBNP (ng/l) & & 6069 & 8732 & $0-376$ \\
\hline Glukose (mmol/l) & 6,3 & 5,5 & & $4,2-6,3$ \\
\hline Kolesterol (mmol/l) & 2,9 & 2,3 & & $3,9-7,8$ \\
\hline LDL-kolesterol (mmol/l) & 1,5 & & & \\
\hline $\mathrm{SR}(\mathrm{mm} / \mathrm{t})$ & & 54 & 7 & $1-19$ \\
\hline CRP (mg/l) & 20 & 14 & $<5$ & $0-5$ \\
\hline ALAT (U/L) & 108 & 129 & 38 & $10-70$ \\
\hline ALP (U/l) & 254 & 301 & 107 & $35-105$ \\
\hline Bilirubin (mmol/l) & 29 & 16 & & $5-25$ \\
\hline GT (U/l) & 251 & 412 & 251 & $15-115$ \\
\hline C-ANCA & & Negativ & & Negativ \\
\hline MPO-ANCA (IU/ml) & & 0,2 & & $0,0-5,0$ \\
\hline PR3-ANCA (IU/ml) & & 0,7 & & $0,0-3,0$ \\
\hline P-ANCA & & Negativ & & Negativ \\
\hline
\end{tabular}

Seks måneder etter utskrivning kunne pasienten berette om rask bedring i funksjonsnivå. Han kunne gå lengre turer uten dyspné. Han har, seks måneder etter innleggelsen, fått ni av 13 planlagte kurer med cyklofosfamid, hvoretter man vil ta stilling til vedlikeholdsbehandling. Han bruker fortsatt prednisolon i nedtrappende doser. Ekkokardiografi etter seks måneder viste bedret venstre ventrikkel-funksjon, med ejeksjonsfraksjon ca. $40 \%$. Pasienten var fortsatt $i$ klinisk bedring.

\section{Diskusjon}

Ved brystsmerter og forhøyede troponinverdier er det først og fremst mistanke om akutt koronarsyndrom med hjerteinfarkt. Disse pasientene skal vanligvis henvises til 


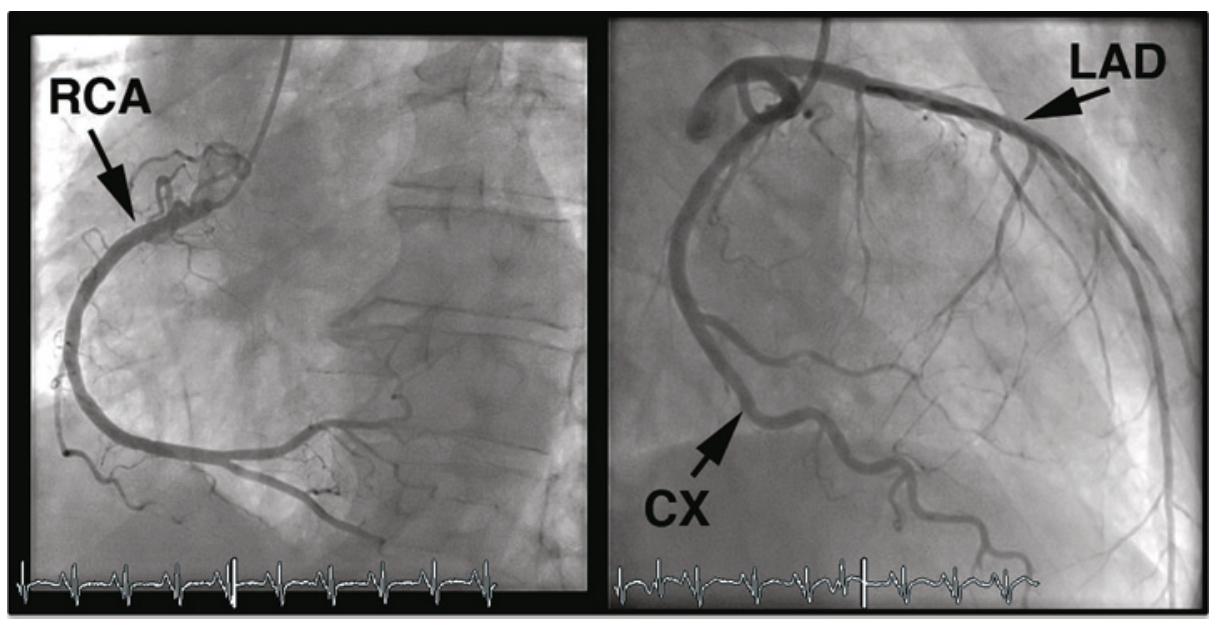

Figur 2 Koronar angiografi. Både høyre og venstre koronararterie hadde veggforandringer, men ingen signifikante stenoser. $L A D$ = fremre nedadstigende gren av venstre koronararterie (left anterior descending artery), $C X=$ venstre bakre koronararterie (circumflex artery), $R C A=$ høyre koronararterie (right coronary artery)

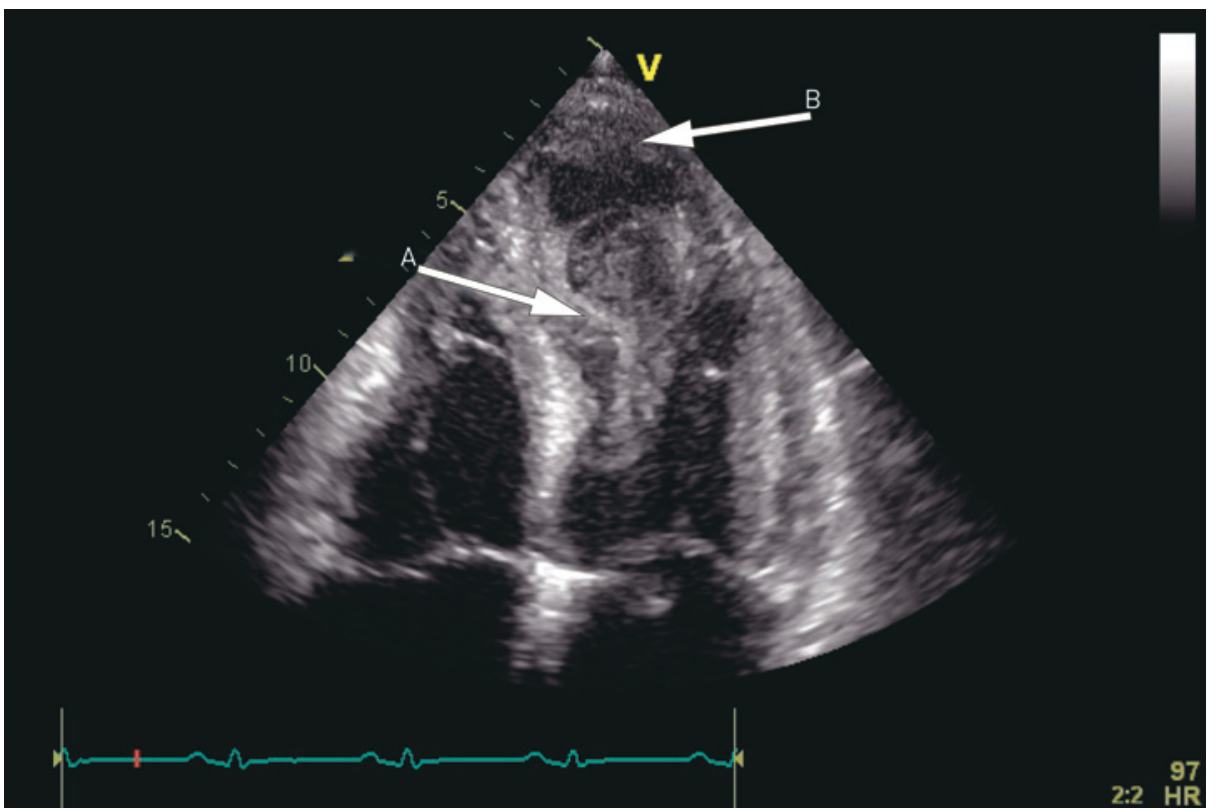

Figur 3 Ekkokardiografisk firekammerbilde av venstre ventrikkel. Venstre ventrikkel-funksjonen var alvorlig redusert. Det var uttalt spontankontrast i apikale halvdel av venstre ventrikkel (A), som tydet på langsom intra ventrikulær blodstrøm. Apeks av venstre ventrikkel var akinetisk, uten at det ekkokardiografisk kunne påvises manifest trombe (B)

koronar angiografi. Ved funn av normale koronarkar eller ved beskjedne koronare forandringer, som hos vår pasient, må annen årsak til troponinstigning vurderes.

Mange tilstander kan gi forhøyede troponinverdier (ramme 1) (9), men hos pasienter uten akutt hjerteinfarkt er troponinverdien ofte kun lett til moderat forhøyet. En viktig differensialdiagnose ved ST-elevasjoner i EKG samt forhøyet troponinnivå er den stressutløste tilstanden takotsubokardiomyopati. I dette tilfellet var denne tilstanden lite sannsynlig, siden man da som oftest ser regionale kontraksjonsforstyrrelser enten apikalt, midtventrikulært eller basalt.
Nest etter hjerteinfarkt er myokarditt en av de vanligste årsakene til betydelig forhøyede troponinverdier. Myokarditt defineres histologisk ut fra Dallas-kriteriene, men disse har begrenset verdi grunnet prøvetakingsfeil, lav sensitivitet og variabilitet $\mathrm{i}$ den histologiske vurderingen $(3,5)$. Ved positiv hjertebiopsi er myokardittdiagnosen sikker. Komplikasjoner relatert til endomyokardial biopsi er relativt sjeldne (3,3\%), men kan være alvorlige (arytmier, ledningsforstyrrelser og perforasjon) (10). Dette er derfor kun indisert hos pasienter hvor biopsien kan ha konsekvenser for behandlingen og dermed kan påvirke prognosen.
MR-undersøkelse av hjertet har i de senere år vist høy sensitivitet og spesifisitet i diagnostikken av akutte myokarditter og er således en alternativ metode for diagnose, uten risikoen ved biopsi (11). Innføringen av nye myokardsensitive sekvenser har gitt mer innsikt $\mathrm{i}$ de patofysiologiske mekanismene ved myokarditt $(4,12)$. De fleste myokarditter i Nord-Amerika og Vest-Europa skyldes virus (5), og disse går i de fleste tilfeller tilbake uten spesifikk behandling.

Vår pasient hadde betydelig forhøyet nivå av eosinofile granulocytter i blodet, noe som ledet utredningen inn på hypereosinofile årsaker til myokarditt. Det er flere hypereosinofile tilstander som kan forårsake endomyokardial skade. Disse inkluderer idiopatisk hypereosinofilt syndrom, maligne tilstander, parasittære infeksjoner, vaskulitter og granulomatøse tilstander, tropisk endomyokardial sykdom, medikamentreaksjoner og transplantatrejeksjon (13). Eosinofil infiltrasjon i vev og påfølgende frigjøring av proteiner kan gi direkte vevs- og endotelskade (14).

Hos vår pasient ga sykehistorien mistanke om eosinofil granulomatose med polyangiitt, basert på debut av astma i voksen alder, nesepolypose, hyppige sinusitter og markant symptomeffekt av steroider. MR-undersøkelse av hjertet ga også støtte til denne diagnosen, og sammenholdt med alvorlig og progredierende hjertesvikt fant vi indikasjon for hjertebiopsi. En sikker diagnose bekreftet ved biopsi var i dette tilfellet viktig, da tilstanden sannsynligvis krever livslang behandling. Ved sikker klinisk diagnose kan imidlertid indikasjonen for biopsi diskuteres (15).

I 1951 beskrev Jacob Churg \& Lotte Strauss en tilstand som inkluderte astma, granulomatøse ekstravaskulære lesjoner og nekrotiske, inflammatoriske og granulomatøse vaskulære forandringer (16). Tilstanden er siden blitt kalt Churg-Strauss' syndrom. I engelsk litteratur anbefales det nå å bruke begrepet «eosinofil granulomatose med polyangiitt» (eosinophilic granulomatosis with polyangiitis, EGPA) fremfor egennavnsbetegnelsen.

Eosinofil granulomatose med polyangiitt er en vaskulitt som involverer små og middels store arterier. Flere organer er affisert som oftest er det lunger og hud, men affeksjon av hjerte, nyrer, gastrointestinale organer og sentralnervesystemet kan også forekomme. I 1980-årene beskrev Lanham og medarbeidere (17) tre suksessive faser av tilstanden: en prodromal fase med astma- og allergisymptomer, en fase med eosinofil infiltrasjon i vev og en siste systemisk fase med utvikling av nekrotiserende vaskulitt.

Gjennomsnittsalder ved diagnosetidspunktet er 50 år. Omtrent $90 \%$ har da astma, som vanligvis har vært til stede 8-10 år før utviklingen av vaskulitt (18). Insidensen er 
RAMME 1

Tilstander utover akutt koronarsyndrom som kan gi forhøyet troponinverdi i serum (9)

Myokardskade relatert til sekundær iskemi (type 2-infarkt)

Arytmi

Aortadisseksjon

Alvorlig aortaklaffsykdom

Hypo- eller hypertensjon

Hjertesvikt

Hypertrof kardiomyopati

Koronar vaskulitt

Myokardskade ikke relatert til iskemi

Hjertekontusjon

Hjertekirurgi

Ablasjonsbehandling

Rabdomyolyse

Myokarditt

Medikamenter

Brannskade

Ikke bestemt eller multifaktoriell gruppe

Takotsubomyopati

Lungeembolisme/pulmonal hypertensjon

Peripartumkardiomyopati

Nyresvikt

Akuttnevrologiske traumer

Infiltrative tilstander

Ekstrem trening

Sepsis

Akutt respirasjonssvikt

Defibrillatorsjokk

mellom 0,5-4,2 per million innbyggere (19). Hjerteaffeksjon ved eosinofil granulomatose med polyangiitt påvises hos $27 \%$ (18). Pasienter med hjerteaffeksjon er oftere ANCAnegative og har høyere nivå av eosinofile celler i perifert blod enn andre rammede (20).

Eosinofil granulomatose med polyangiitt er en alvorlig sykdom, med en rapportert femårsdødelighet på $14 \%$ (21). Stigende alder og hjerteaffeksjon er uavhengige faktorer som predikerer dårligere prognose, mens øre-nese-hals-symptomer er assosiert med bedre prognose. Bruk av prognostiske skåringssystemer ved systemiske nekrotiserende vaskulitter kan være nyttige i beslutningen om hvilken førstelinjebehandling som bør initieres (21).

Behandlingen er primært høydose glukokortikoider, som trappes ned etter hvert som pasienten er i bedring. Hos pasienter med affeksjon av nyrer, hjerte, gastrointenstinale organer eller sentralnervesystemet anbefales cyklofosfamid for å fremme remisjon (22). Vår pasient fikk derfor steroider i kombinasjon med cyklofosfamid. Når pasienter er i remisjon etter behandling med cyklofos- famid anbefales metotreksat eller azatioprin i kombinasjon med steroider. Det finnes ingen sikre data på hvor lenge behandlingen bør pågå, men mye taler for at det er nødvendig med 12-18 måneder, deretter nøye monitorering med tanke på tilbakefall (22).

Vår pasient illustrerer at bak noen av de vanligste symptomene ved indremedisinske avdelinger, brystsmerter og dyspné, kan det skjule seg sjeldne og alvorlige tilstander hvor rask og korrekt diagnose har store behandlingsmessige konsekvenser.

Pasienten har gitt samtykke til at artikkelen blir publisert.

\section{Tobias S. Slørdahl (f. 1982)}

er ph.d., lege i spesialisering og postdoktor. Forfatter har fylt ut ICMJE-skjemaet og oppgir ingen interessekonflikter.

\section{Brage H. Amundsen (f. 1976)}

er ph.d., lege i spesialisering og forsker. Forfatter har fylt ut ICMJE-skjemaet og oppgir følgende interessekonflikter: Han har mottatt reisestøtte fra Pfizer.

\section{Øystein Størkersen (f. 1977)}

er overlege.

Forfatter har fylt ut ICMJE-skjemaet og oppgir ingen interessekonflikter.

\section{Knut Haakon Stensæth (f. 1961)}

er ph.d., overlege og førsteamanuensis II.

Forfatter har fylt ut ICMJE-skjemaet og oppgir ingen interessekonflikter.

\section{Morten Kristian Slette (f. 1952)}

er overlege.

Forfatter har fylt ut ICMJE-skjemaet og oppgir ingen interessekonflikter.

\section{Rune Wiseth (f. 1954)}

er dr.med., overlege og professor og førsteamanuensis II.

Forfatter har fylt ut ICMJE-skjemaet og oppgir ingen interessekonflikter.

\section{Bjørnar Grenne (f. 1978)}

er ph.d., konstituert overlege.

Forfatter har fylt ut ICMJE-skjemaet og oppgir ingen interessekonflikter.

\section{Litteratur}

1. Steg PG, James SK, Atar D et al. ESC Guidelines for the management of acute myocardial infarction in patients presenting with ST-segment elevation. Eur Heart J 2012: 33: 2569-619.

2. Thygesen K, Alpert JS, Jaffe AS et al. Third universal definition of myocardial infarction. Circulation 2012; 126: 2020-35

3. Richardson P. McKenna W. Bristow M et al. Repor of the 1995 World Health Organization/International Society and Federation of Cardiology Task
Force on the Definition and Classification of cardiomyopathies. Circulation 1996; 93: 841-2.

4. Stensaeth $\mathrm{KH}$, Hoffmann P. Fossum E et al. Cardiac magnetic resonance visualizes acute and chronic myocardial injuries in myocarditis. Int J Cardiovasc Imaging 2012; 28: 327-35.

5. Cooper LT Jr. Myocarditis. N Engl J Med 2009. 360: $1526-38$

6. Sinico RA, Bottero P. Churg-Strauss angiitis. Best Pract Res Clin Rheumatol 2009; 23: 355-66.

7. McMurray JJ, Adamopoulos S, Anker SD et al. ESC Guidelines for the diagnosis and treatment of acute and chronic heart failure 2012: The Task Force for the Diagnosis and Treatment of Acute and Chronic Heart Failure 2012 of the European Society of Cardiology. Developed in collaboration with the Heart Failure Association (HFA) of the ESC. Eur Heart J 2012; 33: 1787-847.

8. Kadish A, Dyer A, Daubert JP et al. Prophylactic defibrillator implantation in patients with nonischemic dilated cardiomyopathy. N Engl J Med 2004: 350: $2151-8$

9. Thygesen K, Mair J, Katus H et al. Recommendations for the use of cardiac troponin measurement in acute cardiac care. Eur Heart J 2010; 31. 2197-204

10. Deckers JW, Hare JM, Baughman KL. Complications of transvenous right ventricular endomyocardial biopsy in adult patients with cardiomyopathy: a seven-year survey of 546 consecutive diagnostic procedures in a tertiary referral center. J Am Coll Cardiol 1992; 19: 43-7.

11. Lurz P. Eitel I, Adam J et al. Diagnostic performance of CMR imaging compared with EMB in patients with suspected myocarditis. JACC Cardiovasc Imaging 2012; 5: 513-24.

12. Ferreira VM, Piechnik SK, Dall'Armellina E et al. T(1) mapping for the diagnosis of acute myocarditis using CMR: comparison to T2-weighted and late gadolinium enhanced imaging. JACC Cardiovasc Imaging 2013; 6: 1048-58.

13. Rezaizadeh H, Sanchez-Ross M, Kaluski E et al. Acute eosinophilic myocarditis: diagnosis and treatment. Acute Card Care 2010; 12: 31-6.

14. Pagnoux C, Guillevin L. Churg-Strauss syndrome evidence for disease subtypes? Curr Opin Rheu matol 2010; 22: $21-8$

15. Aakerøy L, Amundsen BH, Skomsvoll JF et al. A 50-year-old man with eosinophilia and cardiomyopathy: need for endomyocardial biopsy? Eur J Echocardiogr 2011; 12: 257-9.

16. Churg J, Strauss L. Allergic granulomatosis, allergic angiitis, and periarteritis nodosa. Am J Pathol 1951: 27: 277-301.

17. Lanham JG, Elkon KB, Pusey CD et al. Systemic vasculitis with asthma and eosinophilia: a clinical approach to the Churg-Strauss syndrome. Medicine (Baltimore) 1984: 63: 65-81.

18. Comarmond C, Pagnoux C, Khellaf M et al. Eosinophilic granulomatosis with polyangiitis (ChurgStrauss): clinical characteristics and long-term followup of the 383 patients enrolled in the French Vasculitis Study Group cohort. Arthritis Rheum 2013; 65: 270-81.

19. Watts RA, Lane S, Scott DG. What is known about the epidemiology of the vasculitides? Best Pract Res Clin Rheumatol 2005; 19: 191-207.

20. Neumann T, Manger B, Schmid M et al. Cardiac involvement in Churg-Strauss syndrome: impact of endomyocarditis. Medicine (Baltimore) 2009; 88: $236-43$

21. Guillevin L, Pagnoux C. Seror R et al. The FiveFactor Score revisited: assessment of prognoses of systemic necrotizing vasculitides based on the French Vasculitis Study Group (FVSG) cohort. Medicine (Baltimore) 2011; 90: 19-27.

22. Bosch X Guilabert A, Espinosa G et al. Treatment of antineutrophil cytoplasmic antibody associated vasculitis: a systematic review. JAMA 2007; 298 $655-69$.

Mottatt 11.4. 2014, første revisjon innsendt 18.8. 2014, godkjent 30.9. 2014. Redaktør: Tor Rosness. 